\title{
Pelatihan Akuntansi Berbasis Aplikasi untuk Mahasiswa Manajemen dan Akuntansi di Jakarta
}

\author{
Machmed Tun Ganyang, Wier Ritonga \\ Program Studi Manajemen Sekolah Tinggi Ilmu Ekonomi Pengembangan Bisnis dan \\ Manajemen (STIE PBM), Jakarta
}

\begin{abstract}
Community Service with the topic of Application-Based Accounting Training for students majoring in management and accounting was chosen because it saw the special needs of the economics faculty. In the era of the industrial revolution 4.0, the era of disruption, especially during the pandemic where the majority of recording, reporting and other processes are done online or work from home, the need for application-based accounting knowledge is very important. It is hoped that after participating in this training activity, partners will be proficient in using accounting applications such as MYOB and Zahir.
\end{abstract}

Keywords Accounting application, $M Y O B$, Zahir

\section{BERDAYA : Jurnal Pendidikan dan Pengabdian Kepada Masyarakat Vol 3, No.2, Agustus 2021, pp.67- 74 eISSN 2721-6381}

\section{Article History}

Received 05 Jun 2021 / Accepted 25 Aug 2021 / First Published: 31 Aug 2021

To cite this article

Tun Ganyang, M., \& Ritonga, W. (2021). Pelatihan Akuntansi Berbasis Aplikasi untuk Mahasiswa Manajemen dan Akuntansi di Jakarta. BERDAYA: Jurnal Pendidikan Dan Pengabdian Kepada Masyarakat, 3(2), 67 - 74

DOI: $10.36407 /$ berdaya.v3i2.384

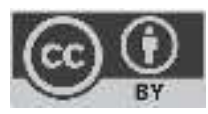

(C) The Author(s)2021

. This open access article is distributed under a Creative Commons Attribution (CC-BY) 4.0 license 


\begin{abstract}
ABSTRAK
Pengabdian Masyarakat dengan topik Pelatihan Akuntansi

Berbasis Aplikasi untuk mahamahasiswa jurusan manajemen dan akuntansi dipilih karena melihat kebutuhan khusus untuk fakultas ekonomi. Di era revolusi industri 4.0, era disrupsi terutama pada masa pandemi dimana mayoritas pencatatan, pelaporan dan proses lainnya dilakukan secara daring atau bekerja di rumah, maka kebutuhan akan pengetahuan akuntansi berbasis aplikasi menjadi sangat penting. Diharapkan setelah mengikuti kegiatan pelatihan ini, mitra akan mahir dalam menggunakan aplikasi akuntansi seperti MYOB dan Zahir.
\end{abstract}

Kata Kunci : Accounting application, $M Y O B$, Zahir
Profil Penulis

Machmed Tun Ganyang, Wier

Ritonga

Program Studi Manajemen Sekolah Tinggi Ilmu Ekonomi Pengembangan Bisnis dan Manajemen (STIE PBM), Jakarta

Korespondensi: Machmed Tun Ganyang email:9anyan9@gmail.com

\section{PENDAHULUAN}

Zahir Accounting adalah suatu software akuntansi laporan keuangan terbaik di Indonesia yang penuh inovasi, fleksibel, berfasilitas lengkap dan berdaya guna tinggi. Software ini berbasiskan Windows 98/2000/NT/XP/Vista. Perintah-perintah didalam software ini menggunakan bahasa Indonesia karena memang software ini dibuat untuk kebutuhan usaha di Indonesia, Oleh karena itu, mudah digunakan dan berbeda dengan software akuntansi lainnya. Zahir Accounting Versi 1.0 dibuat pertama kali pada tahun 1996 dan pada tahun 1997, mulai dikembangkan Versi 2.0 dan mulai dipasarkan pada tahun 1999.

Zahir Accounting telah digunakan lebih dari 2000 perusahaan kecil maupun perusahaan besar dengan 6000 user di Indonesia, telah memperoleh beberapa penghargaan di tingkat nasional. Zahir memiliki banyak keunggulan jika dibandingkan dengan aplikasi jenis software akuntansi yang lain yaitu lebih mudah digunakan (user friendly), dengan tampilan menu dan aliran transaksi yang sederhana dan mudah diingat. Zahir mudah dimengerti oleh orang awam yang tidak mempunyai pengetahuan mendalam mengenai komputer dan akuntansi sekalipun tingkat keamanan (security) yang cukup valid untuk semua user karena memiliki fasilitas password yang dapat mengunci keamanan data akuntansi, menampilkan laporan keuangan komparasi (perbandingan) serta menampilkan analisis laporan dalam untuk grafik.

$M Y O B$ Accounting memiliki banyak keunggulan jika dibandingkan dengan aplikasi jenis software akuntansi yang lain yaitu lebih mudah digunakan (user friendly), dengan tampilan menu dan aliran transaksi yang sederhana dan mudah diingat.Aplikasi Komputer Akuntansi mudah dimengerti oleh orang awam yang tidak mempunyai pengetahuan mendalam mengenai komputer dan akuntansi sekalipun tingkat keamanan (security) yang cukup valid untuk semua user karena memiliki fasilitas password yang dapat mengunci keamanan data akuntansi, menampilkan laporan keuangan komparasi (perbandingan) serta menampilkan analisis laporan dalam bentuk grafik

Salah satu upaya untuk meningkatkan akuntabilitas, pengendalian internal dan keamanan organisasi adalah dengan mengurangi adanya ketidakpahaman yang melaksanakan pencatatan dan membatasi kesalahan pencatatan menggunakan sistem pencatatan yang terkomputerisasi. Untuk itu kegiatan ini bertujuan untuk memberikan pemahaman bagi mahasiswa agar dapat 
mengimplementasikan sistem pencatatan akuntansi yang terkomputerisasi dengan basis program Zahir Accounting dan MYOB.

Dengan kondisi permasalahan pada fakultas ekonomi program studi manajemen dan akuntansi maka dirumuskan masalah bagaimana Peningkatan Keterampilan Penggunaan Aplikasi Zahir Accounting dan MYOB bagi mahasiswa fakultas ekonomi program studi manajemen dan akuntansi di Universitas Islam Attahiriyah.

Pngabdian kepada masyarakat ini mempunyai tujuan sebagai berikut: Meningkatkan Keterampilan Penggunaan Aplikasi Zahir Accounting dan MYOB karyawan dan mahasiswa fakultas ekonomi program studi manajemen dan akuntansi. Meningkatkan peran serta STIE PBM dalam ikut serta mensosialisasikan penggunaan software akuntansi yaitu Zahir Accounting dan MYOB untuk memudahkan dalam memahami pengaplikasian dalam pelaporan keuangan bagi karyawan dan mahasiswa fakultas ekonomi program studi manajemen dan akuntansi.

\section{Sasaran Kegiatan}

Sasaran dari program pelatihan aplikasi akuntansi (Zahir dan MYOB) ini adalah para mahasiswa dan karyawan fakultas ekonomi program studi manajemen dan akuntansi Universitas Islam Attahiriyah. Berdasarkan wawancara dengan beberapa mahasiswa dan karyawan adalah proses pencatatan, penggolongan dan peringkasan laporan keuangan masih dilakukan secara manual, jika dilakukan dengan komputer masih menggunakan Microsoft Office, baik Excel maupun Word.

\section{Manfaat Kegiatan}

Adapun manfaat dari kegiatan pengabdian kepada masyarakat ini adalah: Memberi pengetahuan kepada mahasiswa-mahasiswa fakultas ekonomi program studi manajemen dan akuntansi dan para karyawan untuk dapat menggunakan Zahir Accounting dan MYOB dalam penyajian laporan keuangan. Memberikan pengetahuan kepada mahasiswamahasiswa fakultas ekonomi program studi manajemen dan akuntansi, untuk dapat menggunakan laporan keuangan sebagai alat untuk memproyeksikan rencana usaha kedepannya sebagai salah satu sarana untuk pengambilan keputusan, sehingga dapat lebih bersaing baik di tingkat nasional atau minimal di Jakarta.

\section{MATERI DAN METODE}

\section{Materi}

Metode Pelaksanaan untuk kegiatan pengabdian ini adalah dengan melakukan sosialisasi bagaimana membuat laporan keuangan sesuai dengan penerapan Akuntansi sesuai dengan standar yang berlaku umum dengan menggunakan softwae MYOB Accounting untuk para mahasiswa dan karyawan fakultas ekonomi program studi manajemen dan akuntansi Universitas Islam Attahiriyah Bukit Duri Jakarta Timur yang akan diambil sebanyak lebih kurang 60 peserta.

Berdasarkan identifikasi masalah di atas, agar memperoleh manfaat dari pengabdian ini, maka metode yang ditawarkan dalam pengabdian ini adalah sebagai berikut:

1. Metode ceramah, dimana pengabdi menyampaikan materi tentang fitur- fitur yang ada pada MYOB dengan menjelaskan secara umum terhadap modul yang diberikan;

2. Metode praktek, dimana para mahasiswa mengikuti arahan pengabdi sesuai dengan soal 
yang ada dimodul di computer masing-masing;

3. Memberikan latihan dalam bentuk contoh kasus atau soal;

4. Metode tanya jawab, peserta pelatihan diberikan kesempatan untuk bertanya, dan;

5. Setiap mahasiswa menyimpan hasil pekerjaannya difolder yang telah ditentukan untuk diperiksa.

Namun karena kondisi pandemic, maka metode pelatihan yang digunakan adalah melalui Zoom meeting.

\section{PELAKSANAAN KEGIATAN DAN EVALUASI}

Hasil kegiatan pengabdian pada masyarakat yang telah dilakukan secara garis besar mencakup beberapa komponen, yaitu keberhasilan target jumlah peserta pelatihan, ketercapaian target materi yang telah direncanakan, ketercapaian tujuan pelatihan dan kemampuan peserta dalam penguasaan materi. Ketercapaian target jumlah peserta dapat dilihat dari jumlah peserta yang ditargetkan adalah 60 orang dan pada kenyataannya kegiatan diikuti sebanyak 68 orang sehingga target jumlah peserta telah dapat terpenuhi. Semua peserta dapat mengikuti seluruh proses simulasi dari awal sampai selesai, kegiatan yang dirancang 100\% terlaksana, dan kehadiran kesiapan tim dosen 100\%. Target penyampaian materi simulasi juga tercapai karena materi dapat disampaikan secara keseluruhan. Dengan demikian maka tujuan kegiatan Pengabdian Kepada Masyarakat dapat terpenuhi.
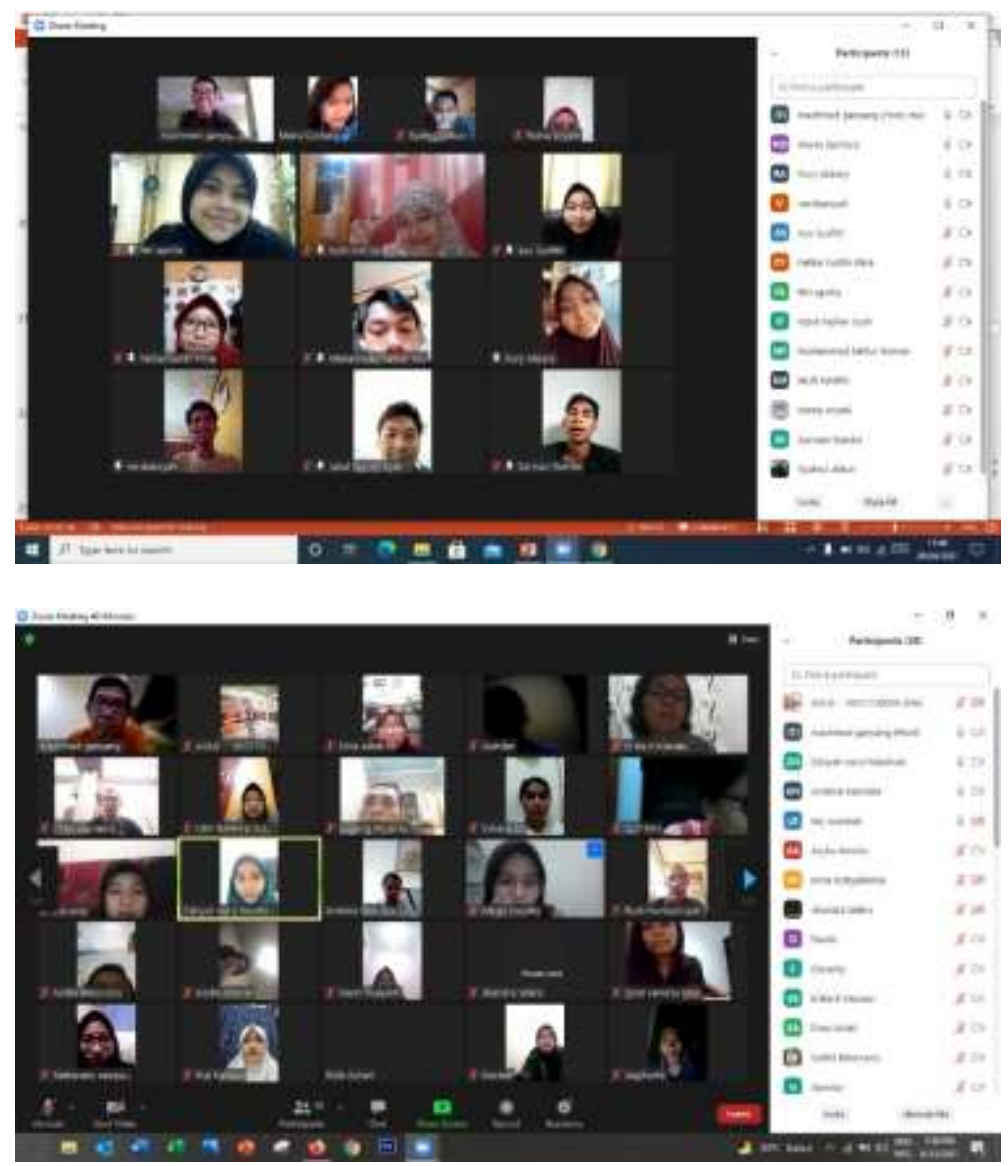

Gambar 1.

Pelaksanaan Kegiatan

Sumber:

Dokumentasi tim di lapangan

\section{Pelaksanaan Kegiatan}

Hasil kegiatan pengabdian pada masyarakat yang telah dilakukan secara garis besar 
mencakup beberapa komponen, yaitu keberhasilan target jumlah peserta pelatihan, ketercapaian target materi yang telah direncanakan, ketercapaian tujuan pelatihan dan kemampuan peserta dalam penguasaan materi. Ketercapaian target jumlah peserta dapat dilihat dari jumlah peserta yang ditargetkan adalah 60 orang dan pada kenyataannya kegiatan diikuti sebanyak 68 orang sehingga target jumlah peserta telah dapat terpenuhi. Semua peserta dapat mengikuti seluruh proses simulasi dari awal sampai selesai, kegiatan yang dirancang 100\% terlaksana, dan kehadiran kesiapan tim dosen 100\%. Target penyampaian materi simulasi juga tercapai karena materi dapat disampaikan secara keseluruhan. Dengan demikian maka tujuan kegiatan Pengabdian Kepada Masyarakat dapat terpenuhi.

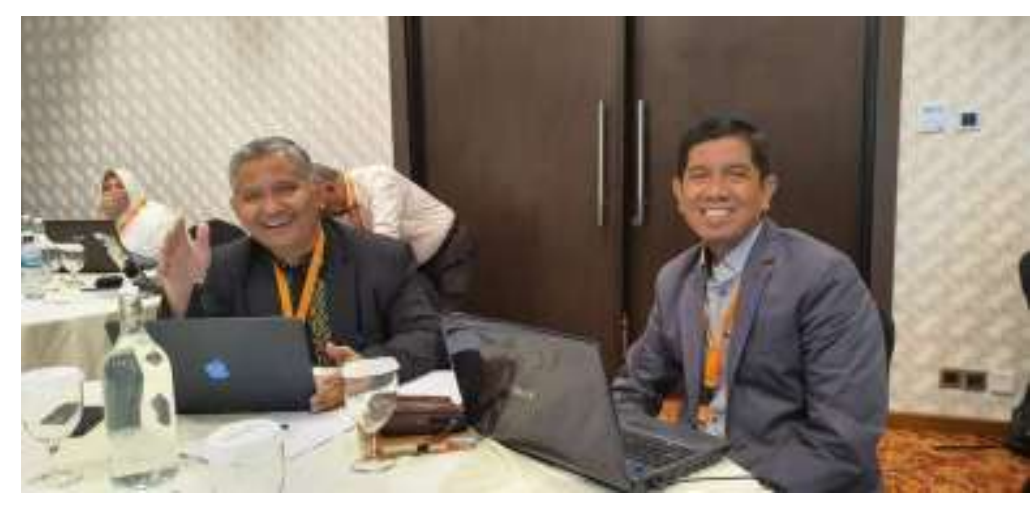

Gambar 2.

Dua Nara Sumber

Sumber:

Dokumentasi tim di lapangan

\section{Evaluasi Kegiatan}

Berdasarkan evaluasi pelaksanaan kegiatan dapat diidentifikasi faktor pendukung dalam pelaksanaan program pengabdian kepada masyarakat adalah: Adanya kerjasama yang baik antara tim pengabdian kepada masyarakat dengan peserta para mahasiswa dan karyawan fakultas ekonomi program studi manajemen dan akuntansi Universitas Islam Attahiriyah. Adanya kerjasama yang baik antara tim pengabdian kepada masyarakat dengan Dekan Fakultas Ekonomi Universitas Islam Attahiriyah beserta jajarannya dalam mendukung terselenggaranya kegiatan ini dalam bentuk pemberian fasilitas Zoom, menghadirkan peserta yang akan diberikan sosialisasi Zahir Accounting dan MYOB serta kesediaan Ketua Program Studi Manajemen dan Akuntansi memberikan kata sambutan sekaligus membuka kegiatan pengabdian kepada masyarakat tersebut. Partisipasi aktif dan antusiasme yang tinggi dari peserta para mahasiswa dan karyawan fakultas ekonomi program studi manajemen dan akuntansi Universitas Islam Attahiriyah dalam mengikuti seluruh rangkaian kegiatan.

Kegiatan pengabdian kepada masyarakat ini dilaksanakan di para mahasiswa dan karyawan fakultas ekonomi program studi manajemen dan akuntansi Universitas Islam Attahiriyah Bukit Duri Jakarta Timur dengan judul "Pelatihan Akuntansi Berbasis Aplikasi Untuk Mahamahasiswa Manajemen Dan Akuntansi Di Jakarta" yang diadakan pada hari Sabtu, 27 Juni 2020 yang dihadiri oleh 68 Peserta, terdiri dari para mahasiswa dan karyawan fakultas ekonomi program studi manajemen dan akuntansi Universitas Islam Attahiriyah Bukit Duri Jakarta Timur. Sesuai dengan tujuan kegiatan pengabdian kepada masyarakat yang telah dilakukan, dapat diambil beberapa kesimpulan sebagai berikut : Meningkatkan peran serta program studi Manajemen Sekolah Tinggi Ilmu Ekonomi Pengembangan Bisnis dan Manajemen (STIE PBM) dalam ikut bekerja sama dengan program studi manajemen dan akuntansi fakultas ekonomi Universitas Islam Attahiriyah melalui kegiatan pengabdian kepada masyarakat dalam bentuk sosialisasi dan peningkatan penggunaan aplikasi piranti lunak Myob Accounting untuk pelaporan keuangan bagi para mahasiswa dan karyawan fakultas ekonomi program studi manajemen dan akuntansi Universitas Islam Attahiriyah 
Bukit Duri Jakarta Timur berjalan dengan baik dan lancar sesuai dengan yang diharapkan; para mahasiswa dan karyawan fakultas ekonomi program studi manajemen dan akuntansi Universitas Islam Attahiriyah Bukit Duri Jakarta Timur telah memiliki pengetahuan dan pemahaman akan pentingnya penggunaan aplikasi piranti lunak MYOB Accounting dalam pelaporan keuangan yang mudah, cepat dan akurat.

\section{SIMPULAN}

Dari pembahasan diatas maka dapat dismpulkan bahwa kegiatan pelatihan piranti lunak Zahir dan MYOB Accounting dilakukan untuk menambah pengetahuan para mahasiswa dan karyawan fakultas ekonomi program studi manajemen dan akuntansi Universitas Islam Attahiriyah tentang penyajian transaksi- transaksi keuangan berbasis komputer. Pelajaran Zahir dan MYOB sendiri sebenarnya sudah dipelajari oleh para mahasiswa dan karyawan fakultas ekonomi program studi manajemen dan akuntansi Universitas Islam Attahiriyah di dalam kelas, akan tetapi materi yang disampaikan oleh pelaksana pelatihan lebih lebih mendalam dengan memberikan kasus-kasus perusahaan dagang yang mungkin masih menjadi hal baru bagi mahasiswa. Perserta yang mengikuti terdiri dari para mahasiswa dan karyawan fakultas ekonomi program studi manajemen dan akuntansi Universitas Islam Attahiriyah Bukit Duri Jakarta Timur yang diambil sebanyak lebih kurang 60 peserta.

Diharapkan pelatihan ini dapat bermanfaat bagi mereka, baik bagi mahasiswa atau karyawan yang ingin melanjutkan ke Program Pasca Sarjana atau dipergunakan dalam dunia kerja nantinya. Karena Jakarta sebagai kota metropolitan, kota bisnis dan wilayah industri yang terdapat banyak perusahaan, keahlian di bidang akuntansi sangat dibutuhkan dalam dunia bisnis. Sesuai dengan tujuan kegiatan pengabdian kepada masyarakat yang telah dilakukan, dapat diambil beberapa kesimpulan sebagai berikut : Meningkatkan peran serta STIE PBM dalam melakukan Kerjasama dengan Universitas Islam Attahiriyah program studi manajemen dan akuntansi melalui kegiatan pengabdian kepada masyarakat dalam bentuk sosialisasi dan peningkatan penggunaan aplikasi piranti lunak Zahir Accounting untuk pelaporan keuangan bagi mahasiswa program studi manajemen dan akuntansi berjalan dengan baik dan lancar sesuai dengan yang diharapkan. Mahasiswa mahasiswa program studi manajemen dan akuntansi telah memiliki pengetahuan dan pemahaman akan pentingnya penggunaan aplikasi piranti lunak Zahir Accounting dalam pelaporan keuangan yang mudah, cepat dan akurat.

\section{Saran Kegiatan Lanjutan}

Berdasarkan kesimpulan di atas, maka dapat kami sarankan hal-hal sebagai berikut: Perlu adanya kegiatan pelatihan penggunaan piranti lunak Zahir Accounting secara bertahap dan berkelanjutan sebagai lanjutan dari kegiatan sosialisasi ini, agar mahasiswa program studi manajemen dan akuntansi tidak hanya sekedar memiliki pengetahuan dan pemahaman terhadap piranti lunak Zahir Accounting akan tetapi mereka benar-benar menggunakan piranti lunak ini dalam membantu pelaporan keuangan dengan mudah, cepat dan akurat. Perlu adanya pendampingan dari instansi terkait.

\section{REFERENSI}

Rudianto. (2012). Pengantar Akuntansi. Erlangga: Jakarta. Modul Pembelajaran $M Y O B$ dan Zahir. 
About Author

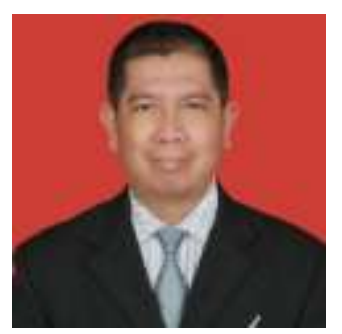

Dr. Machmed Tun Ganyang adalah dosen di Program Studi Manajemen Sekolah Tinggi Ilmu Ekonomi Pengembangan Bisnis dan Manajemen (STIE PBM), Jakarta

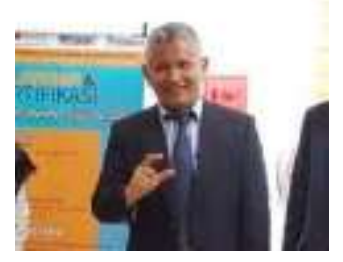

Dr. Wier Ritonga merupakan dosen senior di Program Studi Manajemen Sekolah Tinggi Ilmu Ekonomi Pengembangan Bisnis dan Manajemen (STIE PBM), Jakarta

\section{Declarations}

\section{Funding}

Kegiatan ini merupakan bagian dari program Pengabdian Kepada Masyarakat yang didanai oleh Sekolah Tinggi Ilmu Ekonomi Pengembangan Bisnis dan Manajemen (STIE PBM) tahun 2020.

\section{Competing Interests}

Tidak ada konflik kepentingan untuk diungkapkan. 
BERDAYA: Jurnal Pendidikan dan Pengabdian Kepada Masyarakat Vol 3, No. 2, 2021. 67 - 74. DOI: 10.36407/berdaya.v3i2.348

This page intention to blank........... 